\title{
A Review of Sculpins (COTTOIDEI) of Middle Asia with a Revalidation of the Species Cottus jaxartensis and Description of a New Species Cottus nudus sp. nova
}

\author{
V. G. Sideleva* \\ Zoological Institute, Russian Academy of Sciences, St. Petersburg, 199034 Russia \\ *e-mail: vsideleva@gmail.com \\ Received April 22, 2020; revised July 23, 2020; accepted August 6, 2020
}

\begin{abstract}
Based on the investigations of the representatives of the genus Cottus from Middle Asia, the species status of $C$. spinulosus is supported, and its diagnostic characters are specified. The validity of $C$. jaxartensis is resumed and a degree of its distinction from C. gobio is evaluated. A comparative analysis of morphological characters of the $C$. nasalis holotype and $C$.jaxartensis specimens of the same body size shows identity of these species, and, thus, $C$. nasalis has been included in the synonymy of $C$. jaxartensis. A new species $C$. nudus sp. nova is described. The representatives of this species differ from other Asian species of the genus in the following characters: absence of bony spickles nd dermal tubercles on the skin of the head and trunk; elongated upper jaw terminated near the vertical through posterior margin of orbit; presence of teeth on palatine bones; short sensory canal on the trunk with 23 pores; monochrome light coloration of the fins; and widened distal ends of neural and/or hemal spines in seven caudal centra. A key for the identification of three Middle Asian species ( $C$. spinulosus, $C$. jaxartensis, and $C$. nudus sp. nova) is given.
\end{abstract}

Keywords: sculpins of the genus Cottus, $C$. spinulosus, C. jaxartensis, C. nudus sp. nova, morphology, taxonomy, Middle Asia

DOI: $10.1134 / \mathrm{S} 0032945221030115$

\section{INTRODUCTION}

The sculpins of the genus Cottus from Middle Asia are known in the region of the upper and middle Syr Darya River reaches in the tributaries of the second and third orders. These fishes are distributed in coldwater areas of mountain rivers with sandy and rocky bottom, and they are extremely rarely found in catches. The first two exemplars were observed by Kessler (1872) during the treatment of the collection of A.A. Kushakevich sampled in the springs of Khudzhand city area (Syr Darya River basin). These specimens were used as the syntypes of a new species, Turkestan sculpin Cottus spinulosus Kessler, 1872. Unfortunately, the type specimens of $C$. spinulosus are absent in the catalogues of the Zoological Institute of Russian Academy of Sciences (ZIN) and St. Petersburg University (Yatsenko, 1896; Sideleva et al., 2006; Zhidkov et al., 2019). Based on the first description, Turkestan sculpin is characterized by the following morphological characters: rounded snout; wide interorbital space (1.5 times larger than eye diameter); large and densely distributed bony spickles on head and entire trunk surface (except abdominal side); and short pelvic fins substantially not reaching anal opening. According to Kessler (1872), C. spinulosus is the most similar to European bullhead C. gobio Linnaeus, 1758 based on morphological characters.

The subspecies $C$. gobio jaxartensis has been described based on a specimen from the Ugam River (a tributary of the Chirchik River, Syr Darya River basin) in 1916 (Berg, 1916). This specimen is similar to European nominative subspecies $C$. gobio gobio based on the majority of morphological characters, but it differs in longer pelvic fins. Kottelat (1997) synonymized C. g. jaxartensis with C. gobio, but Turdakov (1959) supported a presence of elongated pelvic fins in C. g. jaxartensis and found several other characters for the distinction of C. g. jaxartensis and C. g. gobio based on extensive material and more careful investigation of morphometric characters. The distinctive characters of $C$. g. jaxartensis are as follows: bony spickles under pectoral fins present (absent in C. g. gobio); tubules of the second pair of nostrils present; short antedorsal distance because of anterior displacement of dorsal fin; and deep first dorsal fin. According to Turdakov (1959), these characters are important, and they are sufficient for the separation of the sculpin into the species $C$. jaxartensis, which is similar to Siberian sculpin C. sibiricus Warpachowski, 1889 based on morphological characters. 
Another species, tubenose sculpin C. nasalis Berg, 1933, was added to the sculpin community of Middle Asia in 1933. It was described based on the single immature and unsuccessfully fixed (with widely opened mouth and spread out gill covers) specimen. The following diagnostic characters were described for this species (Berg, 1933): tubercles on dorsal head surface; bony spickles under pectoral fins; and elongated pelvic fins reaching anal opening.

Based on the additional specimens of $C$. jaxartensis, which were added to the collection of ZIN in 1997 and 2007, the external morphological characters, seismosensory system, and axial skeleton of the species were carefully studied, and its taxonomic position was specified. Besides, a new sculpin species was described after a detailed study of the specimens collected in the Mashat River (a tributary of the Arysi River from the Syr Darya River basin).

The goal of this study is a taxonomic revision of sculpins from Middle Asia with the redescription of C. spinulosus and revalidation and redescription of C. jaxartensis, as well as the description of a new species $C$. nudus sp. nova.

\section{MATERIALS AND METHODS}

This study was based on the specimens deposited to the ichthyological collection of ZIN with related species identification.

C. spinulosus: ZIN 3701, five specimens, Chimkent, 1876, collector N.A. Severtsov; ZIN 14890, 16 specimens, Chimkent, August 20, 1909, collector N. Shavrov; ZIN 30697, six specimens, Chimkent, Badam River, July 12, 1937, collector F.A. Turdakov; ZIN 35881, 13 specimens, Ferghana Valley, spring near Farchad Reservoir, Leninabad, April and May 1953 and 1954, collector V.A. Maksunov.

C. nasalis: ZIN 20741, holotype, Turkestan, Fergana, Syr Darya River basin (without sampling date), collector V.K. Tarantsev; ZIN 22088, eight specimens (juv.), Kel'te-Mashat River, Arysi River basin, $100 \mathrm{~km}$ from Tashkent, August 20, 1923, collector M. Laptev.

C. jaxartensis: ZIN 7799, holotype, Uzbekistan, Ugam River, tributary of Chirchik River, Syr Darya River basin, 1886, collector V.F. Oshanin; ZIN 52795, two specimens, Uzbekistan, Bozsu Channel, Chirchik, Chirchik River basin, July 1997, collector A.M. Prokofiev; ZIN 56574, 25 specimens, Mashat River, tributary of Arysi River, Syr Darya River near Kershetas village, August 12, 2007, collector A.M. Naseka.

The following material was studied for comparative analysis. C. gobio: $\mathrm{MZF}^{1} \mathrm{UK}$ 1889, 18 specimens, Fulda River, Weser River basin, North Sea basin, Hessen, Germany, 1960, collector K. Muller; C. sibiricus: ZIN 6328, lectotype, female $72 \mathrm{~mm} S L$, Yenisei River

\footnotetext{
${ }^{1}$ Finnish Museum of Natural History, University of Helsinki.
}

near Minusinsk, 1876, collector N.M. Mart'yanov; ZIN 56162, 18 specimens, Khalmer-Yu River, lower Ob River basin, June 2008; paralectotypes: ZIN 56235, a specimen, Yenisei River near Minusinsk, 1876; ZIN 6208, a specimen, Yenisei River, 1881, samples of St. Petersburg University; ZIN 6330, a specimen, Abakan River, 1876, collector N.M. Mart'yanov.

The morphometric parameters were obtained based on the modified method (Sideleva et al., 2015). The roentgenograms were applied to study the axial skeleton and fin ray numbers.

The following abbreviations are used in the text and tables: $T L$, total body length; $S L$, standard body length; $c$, head length; $D 1, D 2, P, A, V$, and $C$, number of rays in the first and second dorsal fins, pectoral, anal, pelvic, and caudal fins, respectively; vert., vertebral number. The following terminology is used for the designation of canals and pores of the seismosensory system (Neelov. 1979): CSO, supraorbital canal; $C I O$, infraorbital canal; $C T$, temporal (postorbital) canal; and $C L L$, lateral-line canal of the trunk.

\section{RESULTS AND DISCUSSION}

The findings of Middle Asian sculpins are restricted mainly by the tributaries of the upper and middle reaches of the Syr Darya River (Fig. 1). The sculpins are distributed in the rivers in sparse local communities. Recently the sculpins are found in a tributary of the Sandalash River (Kyrgyzstan) $2254 \mathrm{~m}$ above sea level and in the system of the drainless Talas River (Kustareva and Mamilov, 2012; Vanina and Stejskal, 2017).

\section{Cottus spinulosus Kessler, 1872-Turkestan sculpin}

(Fig. 2, Table 1)

Cottus spinulosus Kessler, 1872. P. 47.

Cottus spinulosus-Berg, 1905. P. 227; Nikolsky, 1938. P. 180; Berg, 1949. P. 1159; Turdakov, 1959. P. 121; Koli, 1969. P. 386; Vanina and Stejskalb, 2017. P. 547.

D i a g n o s i s. Trunk and head (dorsal surface and sides) covered by large and densely distributed bony SPICKLES; interorbital space wide, 1.3-1.5 times larger than horizontal eye diameter; pelvic fins short, substantially not reaching anal opening; pectoral fins short, terminated at a vertical through penultimate ray $D 1$; interbranchial space wide, similar to branchial slit length.

Main meristic characters: $D 17-8, D 2$ 16-18, A 12-14, P 13-14, V 1-4, C 24-27, CLL 32-36.

External morphological characters. Trunk short, its depth near anal fin origin 1.5 times less than maximum body depth. All trunk surface except abdominal part covered by large densely distributed bony SPICKLES reaching bases of caudal fin rays. 


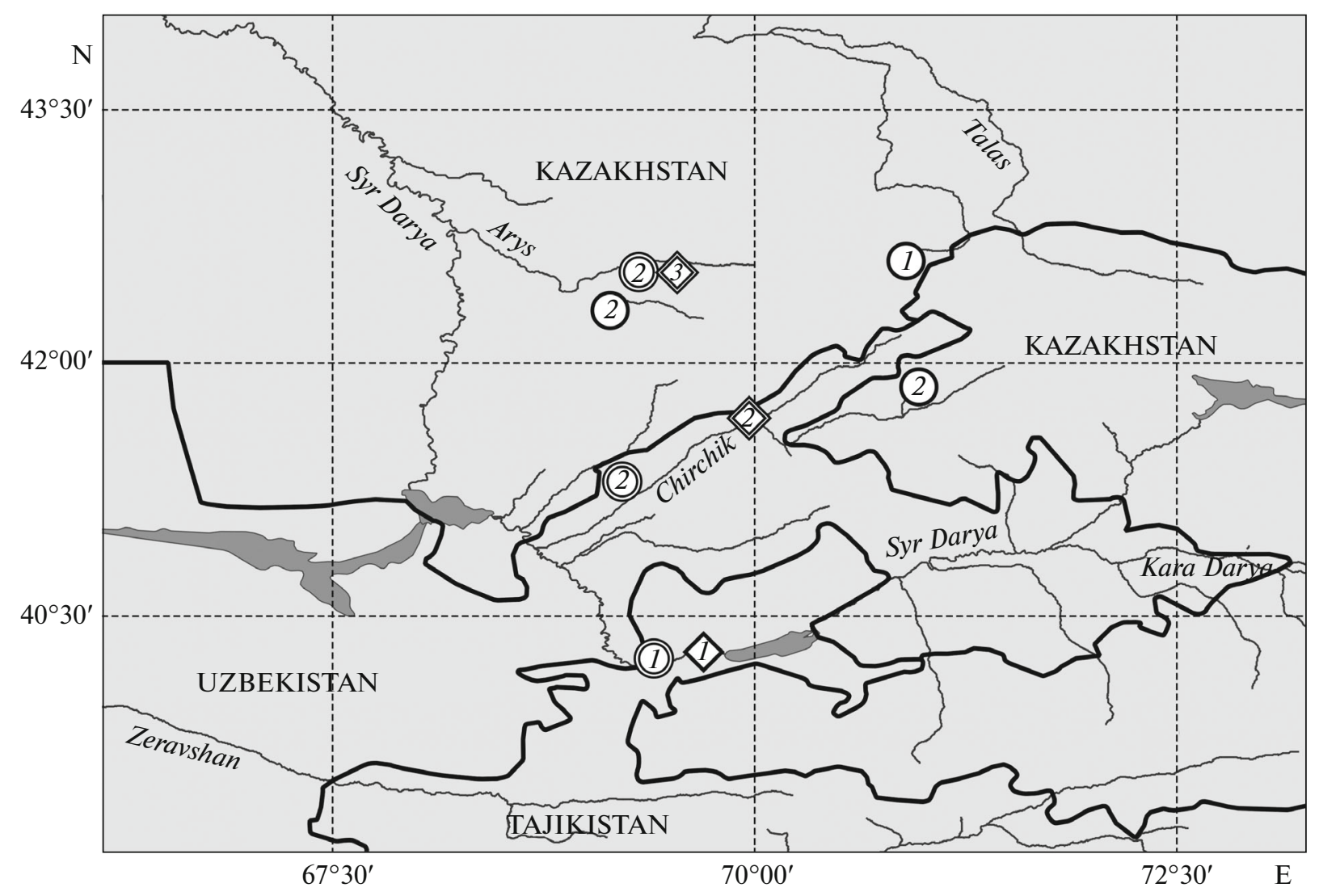

Fig. 1. Sampling sites of (1) Cottus spinulosus, (2) C. jaxartensis, and (3) C. nudus sp. nova in the tributaries of the Syr Darya and Talas rivers: $(\diamond)$ type habitats; $(\bigcirc)$ material of this study; $(\bigcirc)$ literature data.

Head large, covered by large bony SPICKLES on the dorsal surface and sides (similar to their distribution on trunk). Anterior nostrils as wide thick-walled tubules directed to sides; they well-defined on the head surface; posterior nostrils as short and wide tubules. Three spines on preopercle; upper spine well developed, its length $15-18 \%$ in $c$, it sharp, straight, directed posteriorly and upward. Mouth large; upper jaw reaching vertical through anterior $1 / 3$ of eye. Teeth on jaws and vomer small, simple, and not differentiated. Eyes of rounded shape, not convex, i.e., not protruding above head surface. Interorbital space always larger than eye diameter. Interbranchial space wide, 1.2-1.3 times less than branchial slit length.

Dorsal fins attach to each other, rays $D 1$ short; rays $D 2$ almost two times longer than rays $D 1$; anal fin origin at vertical through second ray $D 2$, at small distance (4.2\% $S L$ ) from anal opening; length of fin rays $A$ similar to length of fin rays $D 2$; pelvic fins short, not reaching anal opening at a distance of $6.5-10.0 \% S L$; longest rays $P$ terminated at a vertical through the penultimate or last ray $D 1$. Morphometric characters of the studied specimens are given in Table 1.

Axial skeleton. Total vertebral number 31-32: ABDOMINAL 10-11, CAUDAL 21-22.
Position of first pterygiophore $D 1$ in space between first and second centra, sometimes between second and third centra. First pterygiophore $D 2$ between neural spines of ninth and tenth ABDOMINAL centra. Free interneural between $D 1$ and $D 2$, most often, absent; single free interneural rarely present, its size similar to size of other neural bones supported dorsal rays. Pleural ribs three pairs, they attached to parapophises of three last ABDOMINAL centra. In the complex terminal centrum, hypural plate separated by a wide slit; four or five branched rays and one or two unbranched rays attach to each lobe of hypural plate (Fig. 3). Total number of caudal fin rays 24-27; variability of their number is determined by the number of secondary caudal rays.

Seismosensory system. The structure of this system with all sensory canals (except preoperculo-mandibular canal) connected between each other and represented a single system is usual for the genus Cottus (Fig. 4). Supraorbital canals (CSO) connected by coronary commissure opened by a rounded well-defined pore located on dermal canal protruding above head surface. Each $C S O$ opened outside by two small pores. Infraorbital canal $(\mathrm{CIO})$ with eight pores from which second and third pores large and slit- 

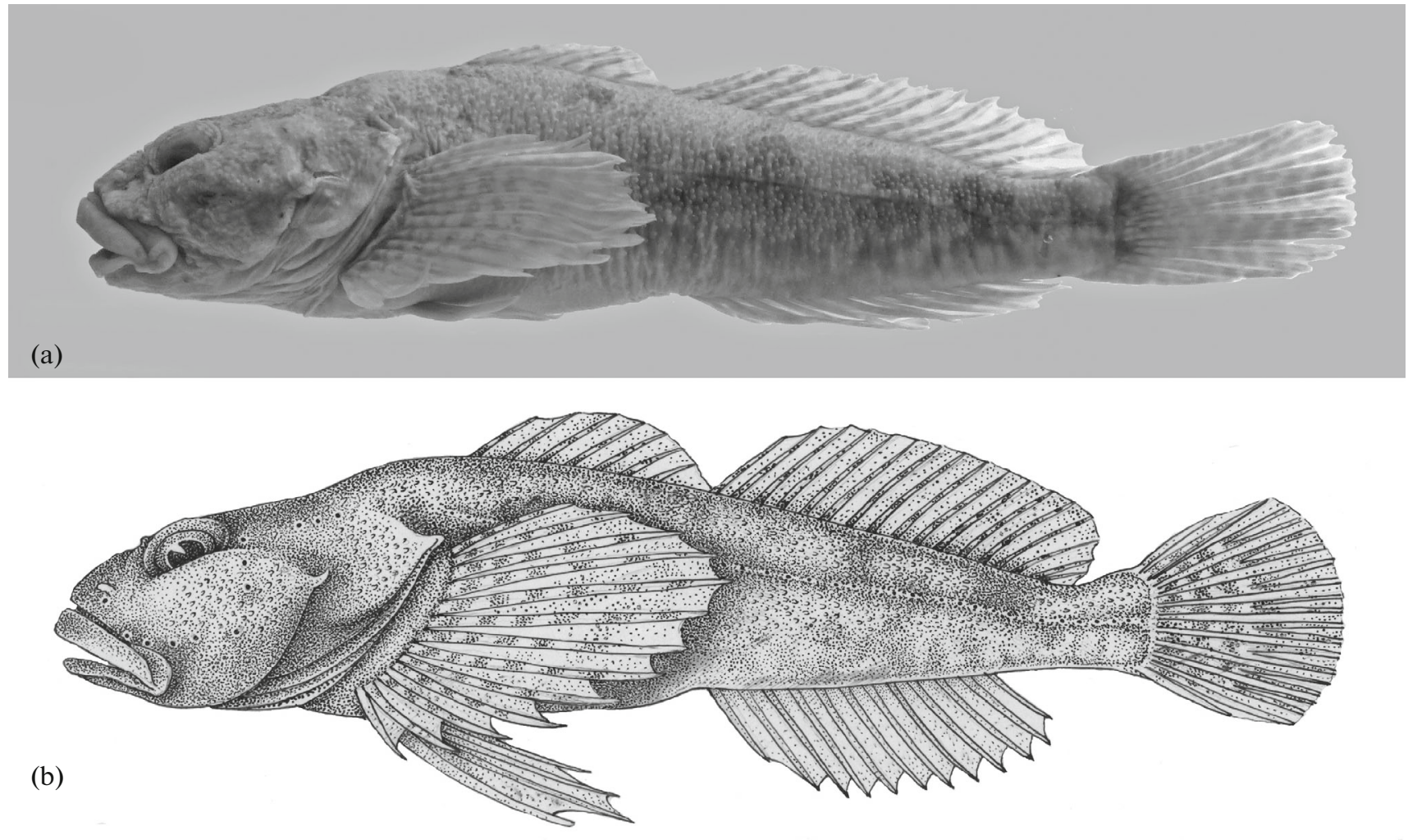

Fig. 2. Cottus spinulosus $70 \mathrm{~mm} S L$ (ZIN 35881): (a) photograph; (b) drawing; the springs flowing into the Farkhat Reservoir.

shaped. Temporal canal and occipital commissure each with three pores. Preoperculo-mandibular canals $(C P M)$ connected between each other on chin; in the site of this connection, a single large pore similar to other pores of these canals in shape and size; fifth $C P M$ pore with additional pore located above the main pore ( $83 \%$ of cases). Lateral line canal on trunk $(C L L)$ with medial-lateral position, reaching bases of caudal fin rays; sometimes, last segment of the canal on middle ray of caudal fin; $C L L$ with $32-36$ small pores.

Coloration of fresh specimens. Fish body with grayish-brown background with small dark blotches on dorsum. Fins with light background; maroon blotches in bases of pectoral fins form transversal bands. Dark blotches of irregular shape on other fins except pelvic fins (Vanina and Stejskal, 2017).

D istribution. Type habitats of $C$. spinulosus are the springs in the area of Khujand (= Leninabad), the Syr Darya River basin, Tajikistan (Kessler, 1872). This species is also observed in the springs flowing into the Farkhad Reservoir near Khudzhand; in the Kel'temashat River of the Arys River basin, $100 \mathrm{~km}$ from Tashkent, Uzbekistan; in the rivers of Shymkent (Chimkent), Kazakhstan; in the Tasbatau River, a tributary of the Teris River, the Asy River basin, Kazakhstan; and in a tributary of the Sandalash River, Kyrgyzstan.
B i ology. The maximum age determined in the fishes from the Tasbastau River was 4 years; and these specimens had $84.2 \mathrm{~mm}, T L, 70.6 \mathrm{~mm} S L$, and $7.92 \mathrm{~g}$ body weight. The spawning of $C$. spinulosus occurred, most likely, in April because the spawners ready for reproduction with gonads at maturity stage IV, as well as ripe and postspawning individuals with gonads at maturity stages V and VI, were observed during this month. The egg diameter was $2-3 \mathrm{~mm}$. The gut content included larvae from the orders Ephemeroptera, Trichoptera, and Plecoptera, as well as from the families Simuliidae, Gammaridae, and Planariidae (Vanina and Stejskal, 2017).

\section{Cottus jaxartensis Berg, 1916}

(Fig. 5, Table. 1)

Cottus gobio jaxartensis Berg, 1916. P. 437.

Cottus nasalis Berg, 1933. P. 701.

Cottus gobio jaxartensis-Nikolsky, 1938. P. 179; Berg, 1949. P. 1148.

Cottus jaxartensis - Turdakov, 1959. P. 129; Turdakov, 1963. P. 121; Mitrofanov et al., 1989. P. 282; Kustareva and Mamilov, 2012. P. 33; Dukravets et al., 2016. P. 68.

Cottus gobio (non Linnaeus, 1758)-Kottelat, 1997. P. 169. 
Table 1. Morphometric characters of three species of the genus Cottus

\begin{tabular}{|c|c|c|c|c|c|c|}
\hline \multirow{3}{*}{ Character } & \multirow{2}{*}{\multicolumn{2}{|c|}{$\begin{array}{c}\text { C. spinulosus } \\
\text { ZIN } 14890,35881(n=25)\end{array}$}} & \multicolumn{3}{|c|}{ C. jaxartensis } & \multirow{3}{*}{$\begin{array}{c}\text { C. nudus } \\
\begin{array}{c}\text { ZIN 56577, } \\
\text { holotype }\end{array}\end{array}$} \\
\hline & & & \multirow{2}{*}{ ZIN 7799, holotype } & \multicolumn{2}{|c|}{ ZIN $56574(n=25)$} & \\
\hline & $\min -\max$ & $M$ & & $\min -\max$ & $M$ & \\
\hline$S L, \mathrm{~mm}$ & $67.6-70.0$ & 69.3 & 100.6 & $67.8-78.7$ & 73.9 & 86.3 \\
\hline$a D$ & $34.7-40.1$ & 36.9 & 29.8 & $29.5-35.8$ & 31.3 & 35.7 \\
\hline$a A$ & $54.8-56.6$ & 55.2 & 51.6 & $51.4-54.0$ & 52.6 & 53.5 \\
\hline$H$ & $20.5-21.6$ & 21.0 & 16.1 & $16.1-22.4$ & 17.7 & 21.4 \\
\hline$l p c$ & 7.9-9.0 & 8.6 & 16.6 & $14.5-17.7$ & 16.7 & 14.9 \\
\hline$h$ & $7.5-10.1$ & 9.1 & 6.7 & $6.7-8.1$ & 7.4 & 7.0 \\
\hline$l D 1$ & $17.6-20.3$ & 18.6 & 22.0 & $18.9-22.5$ & 21.0 & 20.7 \\
\hline$l D 2$ & $36.6-43.7$ & 39.0 & 40.0 & $40.0-45.1$ & 42.2 & 41.1 \\
\hline$I A$ & $27.0-37.5$ & 29.1 & 32.2 & $27.4-32.9$ & 30.9 & 27.5 \\
\hline$h D 1$ & $5.5-7.0$ & 6.3 & 7.0 & $6.1-9.3$ & 7.3 & 7.9 \\
\hline$h D 2$ & $10.0-12.1$ & 11.4 & 11.8 & $11.8-14.1$ & 13.3 & 12.0 \\
\hline$h A$ & $10.4-13.6$ & 11.8 & 14.6 & $9.3-15.0$ & 12.9 & 12.3 \\
\hline$l P$ & $20.5-27.3$ & 24.8 & 27.8 & $26.2-35.1$ & 29.9 & 25.6 \\
\hline$l V$ & $16.3-19.2$ & 18.1 & 20.7 & $20.7-31.9$ & 23.6 & 19.3 \\
\hline$c$ & $31.4-32.8$ & 32.1 & 29.5 & $27.4-35.4$ & 31.2 & 28.5 \\
\hline po & $52.3-55.0$ & 53.7 & 47.5 & $47.4-53.4$ & 49.8 & 52.2 \\
\hline$c H$ & $55.1-62.7$ & 57.6 & 54.1 & $53.3-58.4$ & 54.8 & 53.6 \\
\hline$c w$ & $81.6-100.4$ & 90.0 & 84.7 & $84.8-104.0$ & 88.0 & 85.1 \\
\hline$o$ & $22.2-22.9$ & 22.6 & 19.0 & $19.0-25.5$ & 23.0 & 23.2 \\
\hline io & $24.0-25.7$ & 24.8 & 13.8 & $13.6-16.8$ & 15.9 & 14.5 \\
\hline $\operatorname{lm} x$ & $37.4-42.6$ & 39.8 & 38.0 & $33.0-38.6$ & 34.4 & 51.1 \\
\hline$i b$ & $29.0-41.0$ & 34.0 & 32.5 & $20.5-33.2$ & 32.1 & 30.4 \\
\hline l br.ap & $41.1-53.8$ & 48.6 & 53.2 & $50.0-56.6$ & 52.6 & 54.7 \\
\hline
\end{tabular}

min-max, range of the values; $M$, mean value; here and in Tables 2 and 3: $S L$, standard length; $a D$ and $a A$, antedorsal and anteanal distances; $H$, maximum body depth; $l p c$ and $h$, caudal peduncle length and depth; $I D 1$ and $l D 2$, length of the bases of the first and second dorsal fins; $l A$, length of the anal fin base; $h D 1$ and $h D 2$, depth of the first and second dorsal fins; $h A$, depth of the anal fin; $l P$ and $l V$, length of the pectoral and pelvic fins; $c$, head length; $p o$, postorbital distance; $c H$, head depth near the occiput; $c w$, head width; $o$, horizontal eye diameter; io, interorbital distance; Imx, maxilla length; $i b$, interbranchial width; $l$ br. ap., branchial slit length.

D i a $\mathrm{g}$ n o s i s. Small bony SPICKLES under pectoral fins; caudal peduncle length 1.5-2.0 times larger than its depth; upper head surface covered by dermal tubercles; interorbital space narrow, 1.4-1.5 times less than eye diameter; pelvic fins elongated, reaching anal opening.

Main meristic characters: $D 17-8, D 2$ 16-18, A 12-14, P 13-15, V 1-4, CLL 32-36.

External morphological characters. Trunk shortened, its depth at anal fin base 1.4 times less than maximum body depth. Caudal peduncle comparatively long and narrow, its depth 1.5-2.5 times less than its length. Skin on trunk naked, small bony SPICKLES only under pectoral fins, they located, most often, above and below $C L L$.

Head large, skin on head surface covered by small dermal tubercles. Eyes of oval shape, eye diameter 4.0 times in head length, interorbital space narrow, 1.4-1.5 times less than eye diameter. Anterior nostrils as straight and short pigmented tubules; posterior nostrils as short and wide tubules, these tubules become narrow at the top, and diameter of opening less than tubule diameter. Three well-developed spines on preopercle; upper spine elongated, directed posteriorly and curved inside; two other spines short and hidden in skin. Mouth large, reaching vertical through anterior $1 / 3$ of eye; upper jaw longer and wider than lower jaw; teeth on jaws and vomer present, they small and similar in shape and size; very narrow cartilage layer on lower jaw between teeth plates. Interbranchial space comparatively wide, but 1.5 times less than branchial slit length.

Dorsal fins attach to each other; $D 1$ short and low, its base 2.2 times less than $D 2$ base; $D 2$ elongated $(>40 \% S L)$, terminating near marginal rays of caudal fin; in females, anal fin origin at a small distance $(2.2 \% S L)$ from anal opening; in males, anal fin origin just behind genital papilla at a vertical through second ray $D 2$; pelvic fins elongated, tips of long middle rays $V$ behind anal opening, outermost ray with long and free tip; longest rays of pectoral fin reaching vertical through second or third ray $D 2$; caudal fin of slightly rounded shape with $24-26$ rays. 

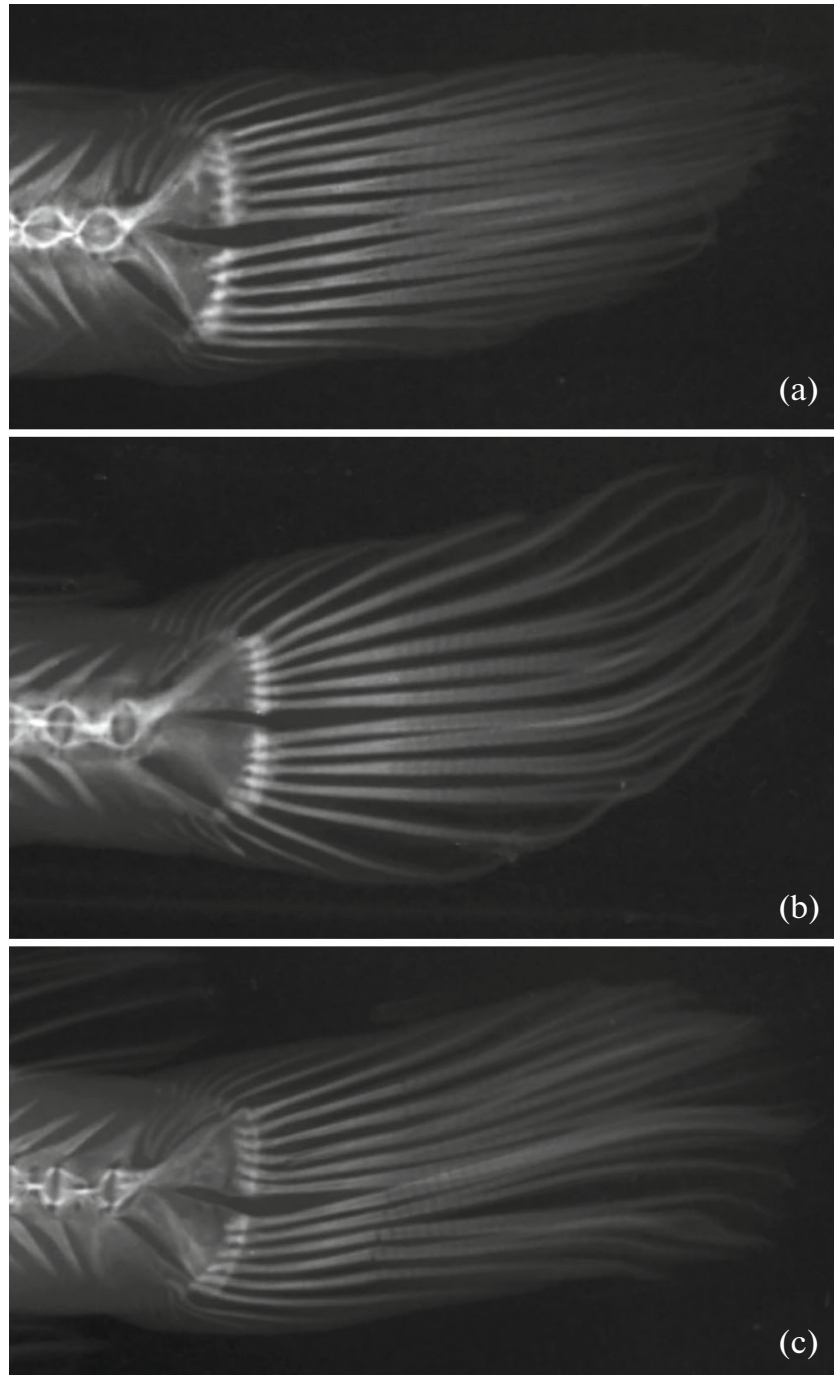

Fig. 3. Roentgenograms of the caudal fins: (a) Cottus spinulosus $(C 5+5)$; (b) C. jaxartensis $(C 4+4)$; (c) variant $C 5+4$ found in $C$. spinulosus (50\% of cases) and $C$. jaxartensis (20\% of cases).

Axial skeleton. Total vertebral number 31-33 (33 in holotype): 10-11 ABDOMINAL and 21-23 CAUDAL centra. Three first ABDOMINAL centra shortened, almost square, all other centra elongated. Neural spines of ABDOMINAL centra high, three times longer than centrum length. Elongated pleural ribs on parapophises of three last ABDOMINAL centra. Position of first pterygiophore with first ray $D 1$ in the space between first and second neural arches of ABDOMINAL centra. All other pterygiophores located one by one in each interneural space. Single free pterygiophore between $D 1$ and $D 2$. Pterygiophore supporting anterior ray $D 2$ located between ninth and tenth ABDOMINAL centra. In anal fin, anterior pterygiophore before first hemal arch. Hypural plate located on complex terminal centrum; two unbranched and four branched rays attach to each side

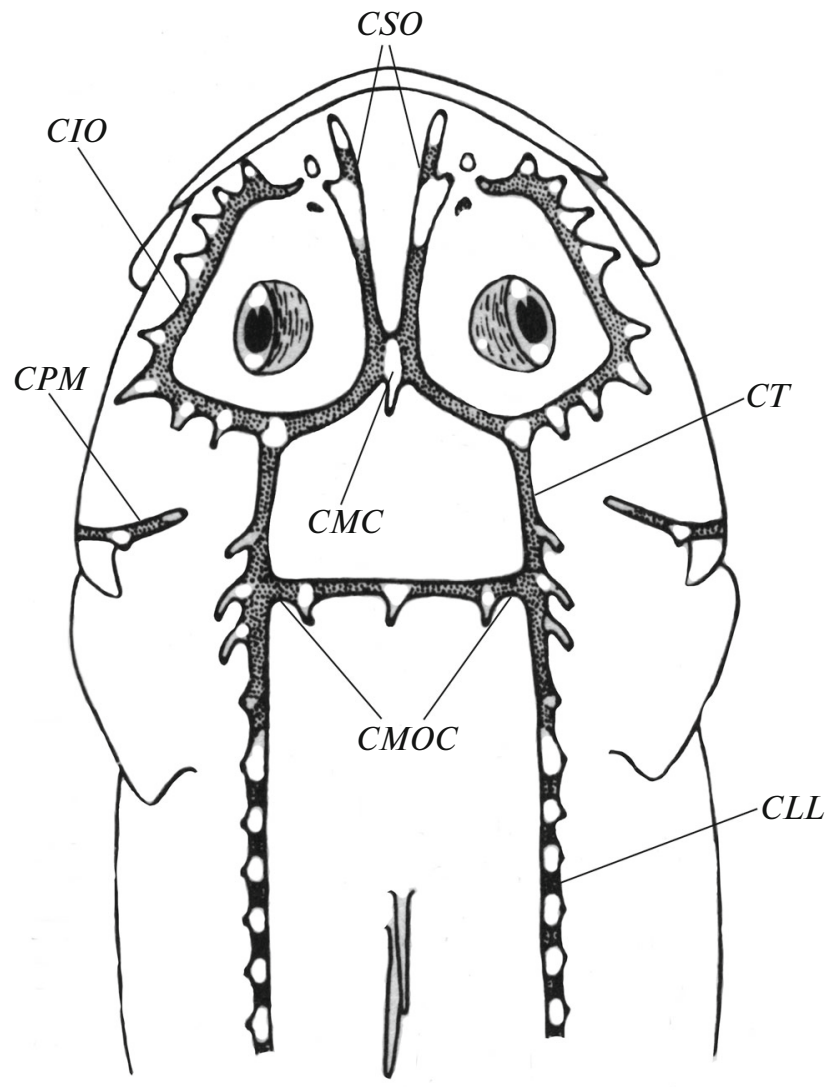

Fig. 4. Topography of sensory canals and pores on the head and anterior part of the body in Cottus spinulosus $70 \mathrm{~mm} S L$ (ZIN 35881). Canals: CSO, supraorbital; CIO, infraorbital; $C T$, temporal (postorbital); $C P M$, preoperculomandibular; $C L L$, lateral-line (trunk); $C M C$, coronal commissure; $C M O C$, occipital commissure.

of hypural plate (Fig. 3b); different numbers of branched rays (four and five) are observed on different sides of hypural plate in $20 \%$ of cases (Fig. 3c).

$\mathrm{S}$ e is mose n s ory syste m. All sensory canals of head (except preoperculo-mandibular canal) connected to each other (Fig. 6). In $C S O$, two small pores or three pores in single cases; in $C I O$, eight pores, and seventh pore in the tip of elongated dermal tubule; in $C T$ and postorbital commissure, three very small pores in each canal; $C P M$ of left and right sides connected to each other, they opened by common large pore on chin; fifth pore double, and, therefore, additional pore present in the canal $(10+1)$; $C L L$ displaced closer to dorsum, reaching caudal fin ray bases, and opened by 32-37 small pores; dermal canals of 35th and 36th pores sometimes directed upward from the sensory canal.

Coloration of fresh specimens (according to Turdakov (1959)). Individual variation in coloration is connected with the size and shape of dark blotches. General background of body light olive green with five or six gray-green or brown blotches. 

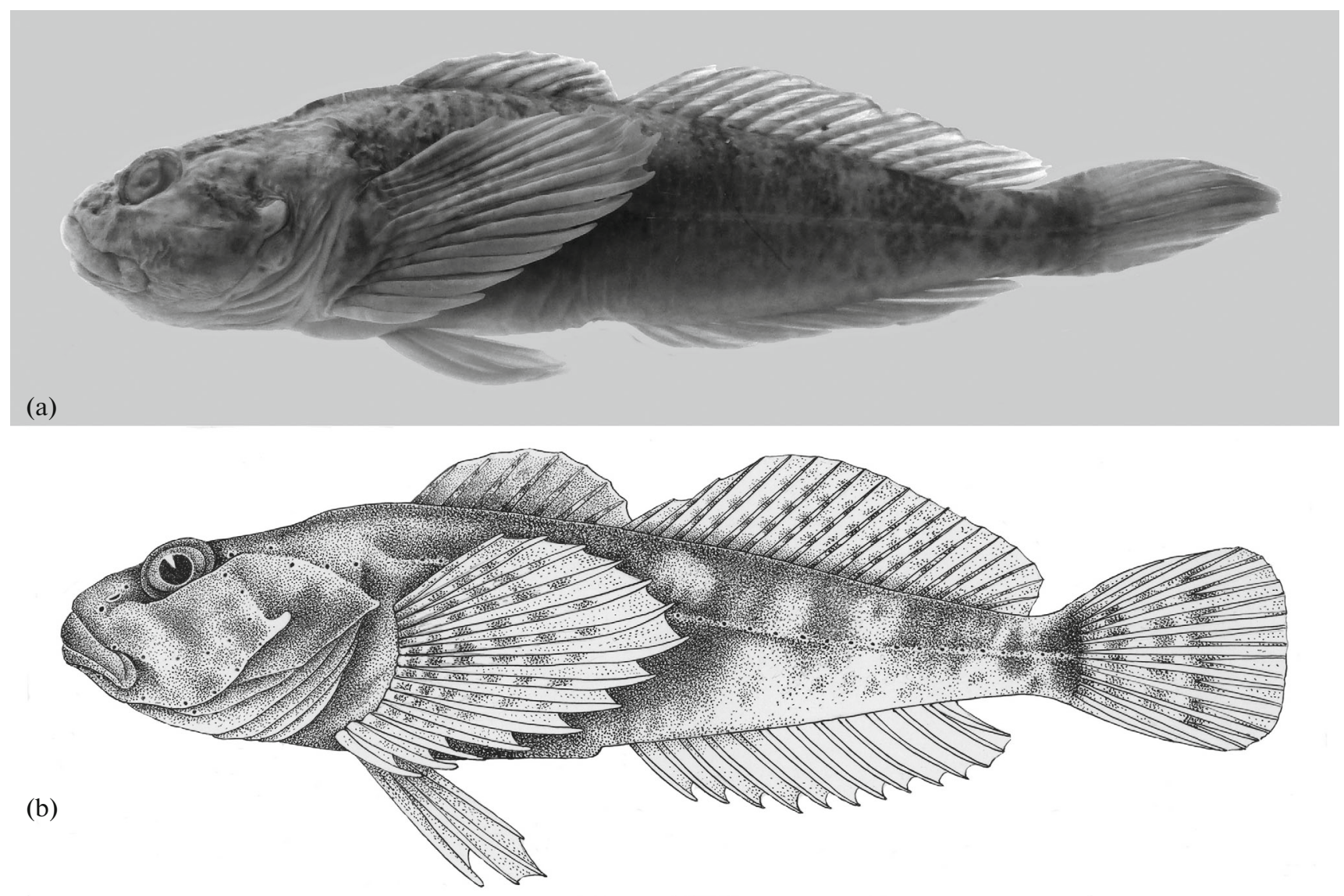

Fig. 5. Cottus jaxartensis $67.8 \mathrm{~mm} S L$ (ZIN 56574): (a) photograph; (b) drawing; Mashat River near Kershetas village.

Dorsal part of head dark, abdominal part of trunk light. Dark blotches and transversal bands on fin rays excluding pelvic rays.

D i s t r ib ut i o n. Type habitat is the Ugam River, a tributary of the Chirchik River, Uzbekistan. The species is also found in the Bozsu Channel, the Chirchik River basin, Uzbekistan; in the Mashat River, a tributary of the Arys River near Kershetas village, Kazakhstan; and in a tributary of the Sandalash River, Kyrgyzstan. According to Turdakov (1959), the representatives of the species were observed in the Badam and Kochkar-Ata (=Koshkar Ata, a tributary of the Badam River) rivers near Shymkent (Chimkent), Kazakhstan.

B i olog $\mathrm{y}$. There is very little information on the biology of $C$. jaxartensis. Maximum body length $(118.4 \mathrm{~mm} T L)$ is reported for the holotype. The exemplars $58 \mathrm{~mm} T L$ are sexually mature (Turdakov, 1959). The food in the guts of fishes from the rivers near Shymkent (Kazakhstan) included Ephemeroptera and Trichoptera larvae, as well as Amphipoda and small imago insects (Turdakov, 1959).

Comparative comments. At present, 28 specimens (including the holotype) identified as
C. jaxartensis based on morphological and diagnostic characters are stored in the ichthyological collection of ZIN. Based on new samples from the Mashat River (a tributary of the Arys River, the Syr Darya River basin), a comparison with the specimens of $C$. gobio from the Fulda River (Germany) has been conducted. The following morphological characters are used for the distinction of C. jaxartensis and C. gobio (Table 2): development of bony SPICKLES on the body, shape of anterior pair of nostrils, coloration of all fins, and pelvic fin length. Based on unique combination of C. jaxartensis characters, its species status suggested previously by Turdakov (1959) has been supported.

In a faunistic review "Fishes of Kazakhstan" (Mitrofanov et al., 1989), Middle Asian tubenose sculpin C. nasalis is described as synonym of $C$. jaxartensis. Based on the first description of an immature specimen of the former species (ZIN 20741), the main diagnostic characters are as follows: the structure of both pairs of nostrils located on well-defined tubules and a light general background of the fins (Berg, 1933). The specimens from the collections (ZIN 22088) identified previously as $C$. nasalis are referred to C. spinulosus in this study because of the presence of specific large SPICKLES on the head and trunk. 


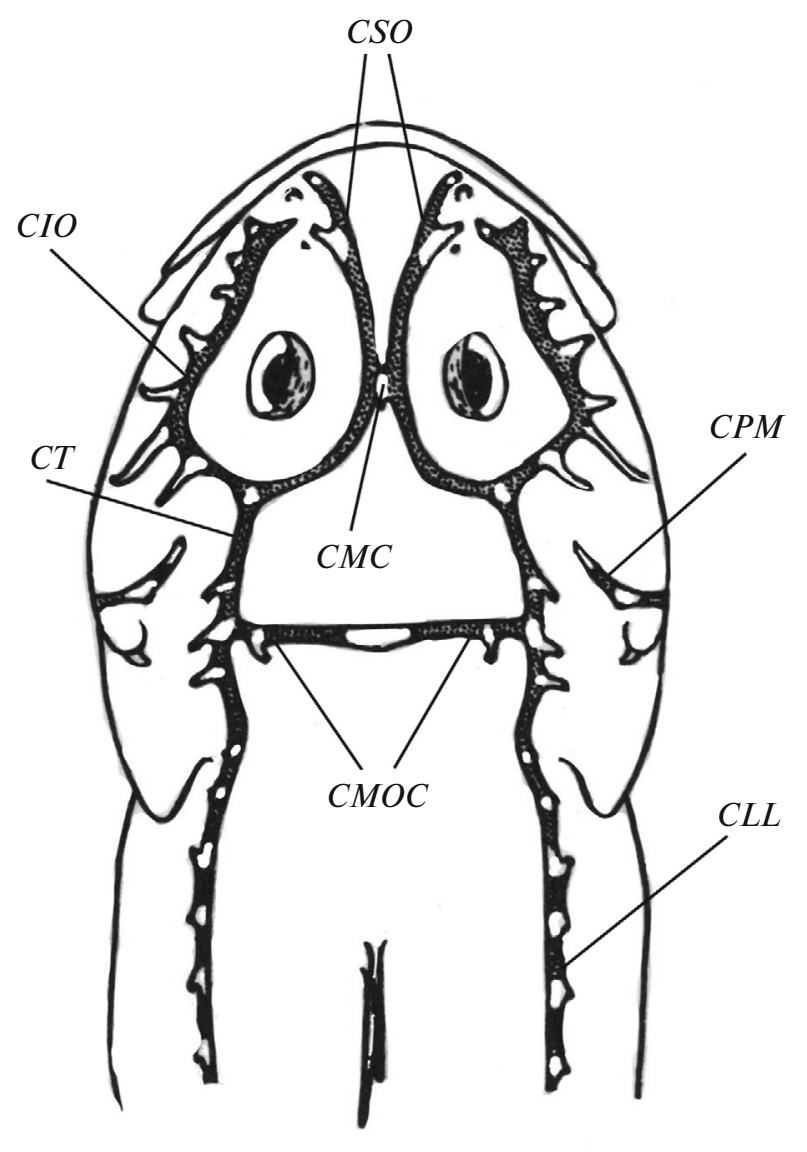

Fig. 6. Topography of sensory canals on the head and anterior part of the body in Cottus jaxartensis $100.6 \mathrm{~mm} \mathrm{SL}$; holotype (ZIN 7799); designations see in Fig. 4.

Based on the comparative analysis of morphological characters (structure of nostrils, coloration, shape and size of fins, presence of SPICKLES under the pectoral fins, presence of dermal tubercles on the dorsal head surface, etc.) and meristic characters in the specimens of $C$. jaxartensis and $C$. nasalis holotype of similar body size, these species are identical (Table 3). Therefore, according to nomenclature rules, C. nasalis Berg, 1933 is included in synonymy of $C$. jaxartensis Berg, 1916.
During the investigation of the samples from the Mashat River (a tributary of the Arys River), a specimen differed by several characters from known species of Middle Asian sculpins (C. spinulosus and C. jaxartensis), as well as from other Eurasian sculpins of the genus Cottus, was found. Based on this specimen, a new species of the genus Cottus is described below.

\section{Cottus nudus sp. nova-naked sculpin}

(Fig. 7, Table. 1)

Holotype: ZIN 56577, $86.3 \mathrm{~mm} S L$, male, Mashat River, a tributary of Arys River, Syr Darya River basin, near Kershetas village, Turkestan oblast, Kazakhstan, August 12, 2007, collector A.M. Naseka.

Diagnosis. Skin on head and trunk naked, bony SPICKLES and dermal tubercles absent; mouth large, upper jaw almost not reaching vertical through posterior margin of eye; teeth on palatine bones; lateral line sensory canal incomplete, terminated at vertical through 15 th ray $D 2$, with 23 pores; second dorsal fin, anal, caudal, and pelvic fins light without black blotches and bands. Pectoral fin with dark blotches, wide base, and 18 rays.

Main meristic characters: $D 18, D 217$, A 14, P 18, V1-4, CLL 23.

Description. Trunk elongated, its depth at anal fin origin 1.3 times less than maximum body depth. Caudal peduncle elongated; its length 2.1 times larger than its depth. Skin on trunk naked, bony SPICKLES absent. Head small, flattened, its depth near occiput 1.6 times less than its width. Skin on head smooth, dermal structures (tubercles or wrinkles) absent. Eyes of oval shape, 4.3 times in $c$; interorbital space narrow, 1.6 times less than eye diameter. Anterior nostrils located on well-defined weakly pigmented tubules; posterior nostrils on very short, wide, and unpigmented tubules. On preopercle, three spines covered by skin; upper spine most developed, directed posteriorly and curved inside; two other spines short and directed anteriorly. Mouth large, upper jaw almost reaching posterior margin of eye, it longer and wider than lower jaw; teeth on jaws and vomer numerous, small, they larger in internal rows than in external rows; two teeth rows on palatine bones. Interorbital

Table 2. Morphological characters for the distinction of the similar size specimens of Cottus jaxartensis and C. gobio

\begin{tabular}{|c|c|c|}
\hline Character & Cottus jaxartensis & Cottus gobio \\
\hline Body shape & $\begin{array}{l}\text { Trunk shortened, } H \text { (at } D 1 \text { base) } 4.5 \text { times } \\
\text { in } S L\end{array}$ & $\begin{array}{l}\text { Trunk proportionally elongated, } H \text { (at } D 1 \text { base) } \\
6.0 \text { times in } S L\end{array}$ \\
\hline Bony spickles & $\begin{array}{l}\text { Small and densely distributed spicklea } \\
\text { always present under pectoral fins }\end{array}$ & Absent \\
\hline Fin coloration & $\begin{array}{l}\text { Light and monochromous, without dark } \\
\text { blotches }\end{array}$ & $\begin{array}{l}\text { Dark blotches grouped into bands in all fins } \\
\text { (except pelvic fins) }\end{array}$ \\
\hline Pelvic fins & Elongated reaching anal opening & Short, substantially before anal opening \\
\hline $\begin{array}{l}\text { Shape of the anterior pair } \\
\text { of nostrils }\end{array}$ & $\begin{array}{l}\text { Thick-walled unpigmented tubules } \\
\text { directed to the sides }\end{array}$ & Thin-walled pigmented tubules \\
\hline
\end{tabular}




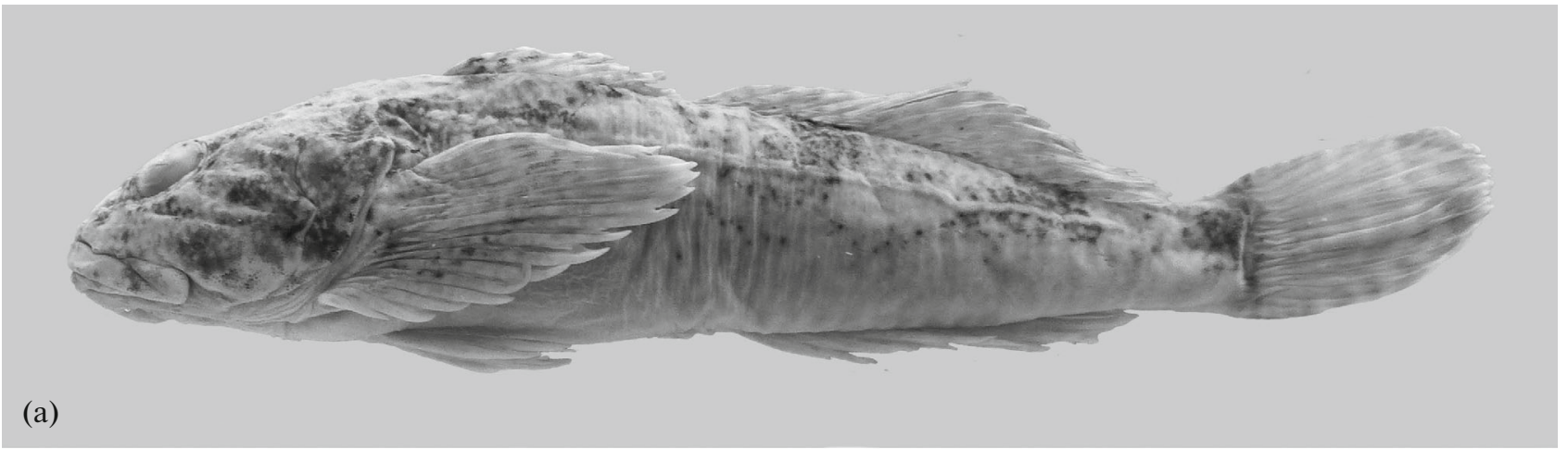

(a)

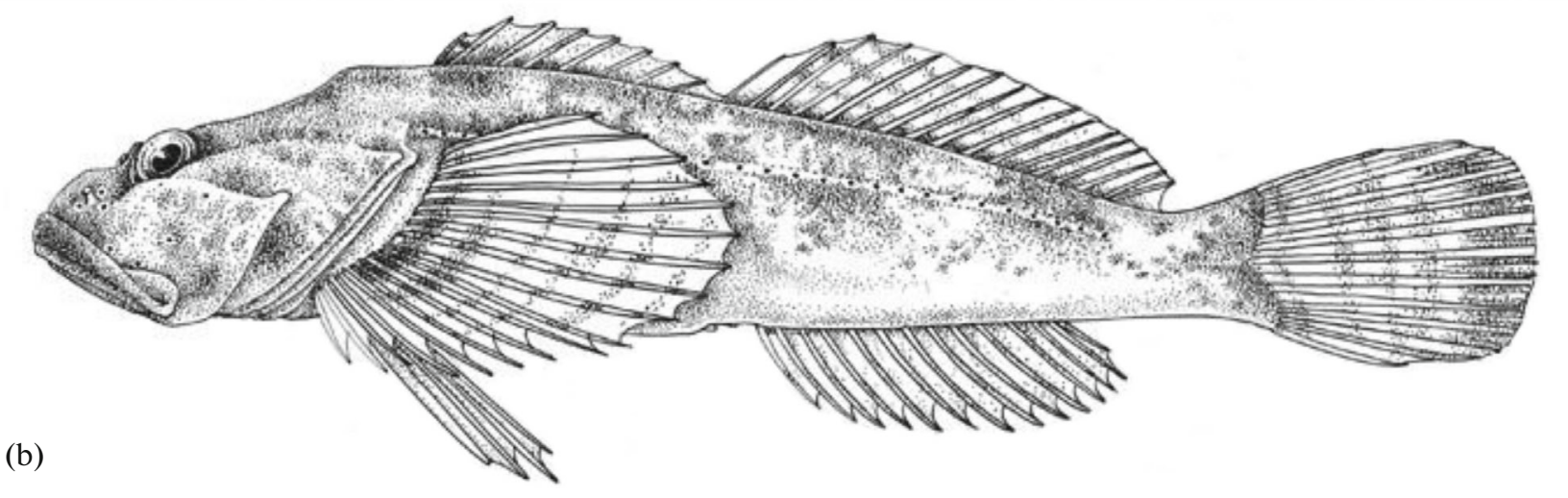

Fig. 7. Cottus nudus sp. nova $86.3 \mathrm{~mm} S L$ : (a) photograph; (b) drawing; holotype (ZIN 56577); Mashat River near Kershetas village, tributary of the Arys River, Syr Darya River basin.

space not wide, 1.8 times less than branchial slit length.

Dorsal fins attach to each other, length of $D 1$ ray similar to eye diameter; $D 2$ deep, not reaching marginal rays of caudal fin at a distance of $8.0 \% S L$; anal fin origin at vertical through second ray $D 2$, at a distance (3.5\% SL) from anal opening; length of rays in $A$ and $D 2$ similar; pectoral fins short, terminating at vertical through first ray $D 2$; special features of pectoral fins are wide base and large number of rays (18); pelvic fins short, not reaching anal opening at a distance equal to $43 \% \mathrm{~V}$; caudal fin of slightly rounded shape.

Axial ske le to n. Total vertebral number 33: 11 ABDOMINAL and 22 CAUDAL centra (Fig. 8). Neural spines of first and second centra substantially close to each other. Three pairs of pleural ribs on three last ABDOMINAL centra. Eight rays in $D 1$, first spined ray supernumerary; typical ray of eighth pterygiophore absent and ninth pterygiophore transformed into interneural (terminology according to Yabe (1985)); two pterygiophores of dorsal fin inserted between eighth and ninth centra, each of other pterygiophores located in each interneural space. In $D 2,17$ rays; first pterygiophore $D 2$ inserted before first postanal centrum; pterygiophore between first and second centra absent; second pterygiophore $D 2$ inserted before third centrum. Posterior pterygiophore $D 2$ inserted between preural $(p u) 9-10$ and supports two posterior rays of this fin. In anal fin, 14 rays; first ray typical; two pterygiophores $A$ located before first hemal arch; second interhemal space empty because third pterygiophore located before hemal arch of third CAUDAL centrum. Posterior pterygiophore $A$ located between $p u 10-p u 11$ and supports two last rays. In caudal fin, 29 rays; external primary rays not branched, branched rays ten; three epurals; neural arch pu2 shortened in this species, in other Cottus species it elongated (Yabe, 1985). Complex terminal centrum fused with single hypural plate separated posteriorly by deep cut. Neural and/or hemal spines of $p u 2-p u 8$ centra distally widened (Fig. 8), similar widenings on CAUDAL centra not observed in other Cottus species.

$\mathrm{S}$ e is mose n s ory syste $\mathrm{m}$ is characterized by the typical structure for the genus Cottus when all sensory canals (except preoperculo-mandibular canal) are connected into common system (Fig. 9). Supraorbital canals (CSO) are connected by coronary commissure opened by single small pore; $C S O$ with three pores in its precoronary part; infraorbital canal $(C I O)$ with eight pores: second and third pores large and slitshaped, and fifth pore located in the end of elongated dermal tubule; temporal canals $(C T)$ and occipital commissure connecting left and right canals with three pores in each canal; lateral line (trunk) canal located closer to dorsum, it incomplete terminating at vertical through 15 th ray $D 2$, with 23 small pores. 


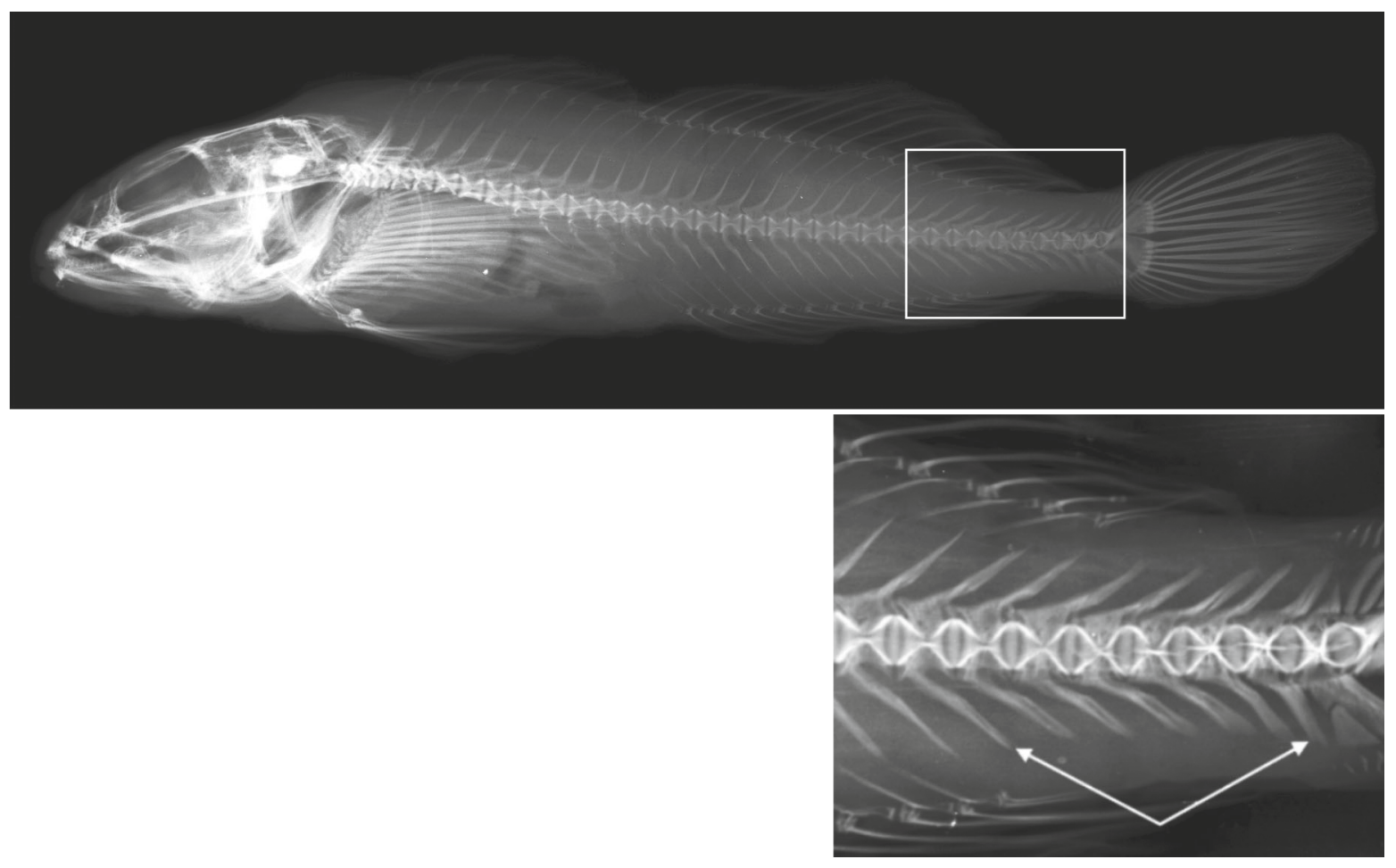

Fig. 8. Axial skeleton of Cottus nudus, holotype; $(\rightarrow)$ widened distal ends of hemal spines.

Coloration of holotype fixed in e $t h$ a $n$ o l. Trunk with light background and groups of melanophores; they form dark blotches of irregular shape closer to dorsum, near $D 1$ origin, in area of first and last rays $D 2$, and near bases of caudal fin rays. Melanophores concentrated into dark band on dorsal surface of head; this band distributed on snout area, interorbital space (including dermal folders of eyes), and posterior part of head. Second dorsal fin, anal fin, and pelvic fins light; small separated dark blotches on $D 1$ and $P$; caudal fin light except its more dark distal part.

Distribution. At present, only the sampling site of the holotype is known: the Mashat River, a tributary of the Arys River near Kershetas village, Kazakhstan.

E t y molog y. The species name «nudus» is connected with naked skin on the head and trunk and absence of bony spickles and dermal outgrowths.

Comparative comments. The sculpins of Middle Asia are morphologically heterogeneous. Two species (C. spinulosus and C. jaxartensis) are similar to C. sibiricus in the presence of sspickles on the trunk, completed lateral line canal with $32-36$ pores, and shape of the upper spine on the preopercle. The new species $C$. nudus is similar to Volga $C$. koshewnikowi (Sideleva et al., 2015) in incomplete lateral line canal with 23 pores, but it differs in the absence of bony spickless on the trunk and dermal "wrinkles" on the head.

\section{IDENTIFICATION KEY FOR MIDDLE ASIAN SCULPINS OF THE GENUS COTTUS}

1. Bony spickles on trunk present; lateral line completed, reaching bases of caudal fin rays, with $32-36$ pores.

1a. Bony spickles only under pectoral fins, they always absent on head. Interorbital space narrow, less than eye diameter. Pelvic fins elongated, reaching anal opening

Cottus jaxartensis

1b. Bony spickles on trunk and head present. Interorbital space wide, larger than horizontal eye diameter. Pelvic fins short, substantially not reaching anal opening

Cottus spinulosus

2. Skin naked, bony spickles absent; lateral line incomplete, not reaching $C$ base, terminating at vertical through 15th ray $D 2$, with 23 pores. Cottus nudus

\section{ACKNOWLEDGMENTS}

I'm grateful to Z.V. Zhidkov (ZIN, Russian Academy of Sciences) for help in preparation and analysis of roentgenograms as well as to A.M. Naseka (St Petersburg University) for the collection of Middle Asian sculpins in the Mashat River and the artist N.A. Florenskaya for the drawings of naked sculpin.

\section{FUNDING}

This study was conducted according to State target AAAAA17-117030310197-7. 

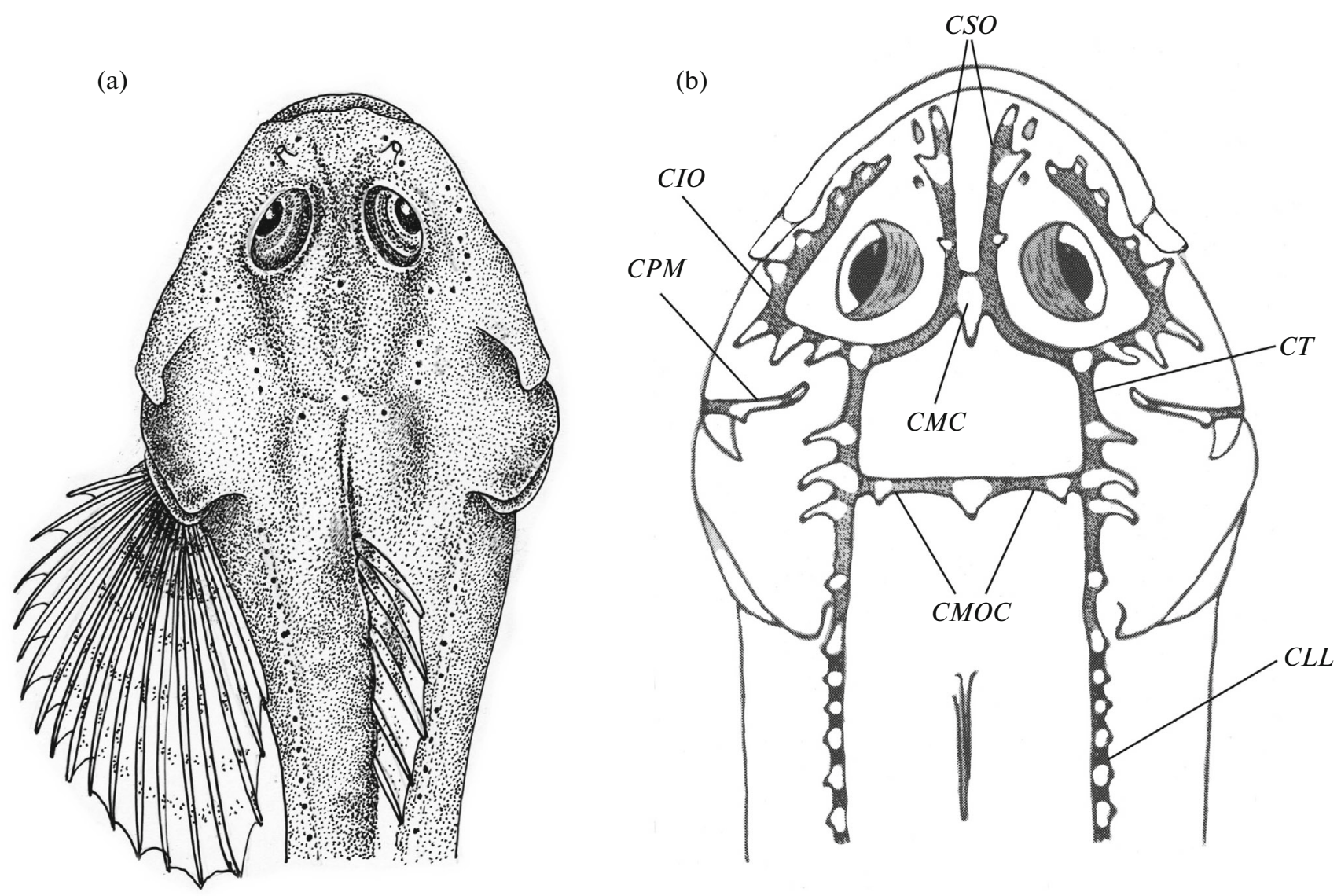

Fig. 9. Cottus nudus sp. nova: (a) head and (b) topography of sensory canals and pores on the head and anterior body part in the holotype; designations see in Fig. 4.

\section{COMPLIANCE WITH ETHICAL STANDARDS}

Conflict of interests. The author declares that she has no conflict of interests.

Statement on the welfare of animals. All applicable international, national, and/or institutional guidelines for the care and use of animals were followed.

\section{OPEN ACCESS}

This article is licensed under a Creative Commons Attribution 4.0 International License, which permits use, sharing, adaptation, distribution and reproduction in any medium or format, as long as you give appropriate credit to the original author(s) and the source, provide a link to the

Table 3. Morphological characters of Cottus nasalis (holotype) and C. jaxartensis

\begin{tabular}{|c|c|c|}
\hline Character & C. nasalis ZIN 20741, holotype $51.5 \mathrm{~mm} S L$ & $\begin{array}{l}\text { C. jaxartensis ZIN } 22088 \text {, three specimens } \\
52.1-52.4 \mathrm{~mm} S L\end{array}$ \\
\hline Body shape & $\begin{array}{l}\text { Trunk shortened, body depth at } A \text { base } 1.6 \\
\text { times in } H\end{array}$ & $\begin{array}{l}\text { Trunk shortened, body depth at } A \text { base } 1.5 \\
\text { times in } H\end{array}$ \\
\hline Bony spickles & Present under pectoral fins & $\begin{array}{l}\text { In immature specimens, sometimes reaching } \\
\text { vertical through middle } D 2\end{array}$ \\
\hline $\begin{array}{l}\text { Nostril structure: } \\
\text {-anterior }\end{array}$ & Well defined, located on $t$ & ick-walled elongated tubules \\
\hline -posterior & Short tubules & Tubules with variable height \\
\hline $\begin{array}{l}\text { io } \\
\text { Size of fins: }\end{array}$ & Less than $o$ at 1.4 times & Less than $o$ at 1.5 times \\
\hline $\begin{array}{l}-P \\
-V\end{array}$ & $\begin{array}{r}\text { Elongated reaching vertical } \\
\text { Elongated reac }\end{array}$ & $\begin{array}{l}\text { hrough third or fourth ray } D 2 \\
\text { ing anal opening }\end{array}$ \\
\hline $\begin{array}{l}C L L \\
\text { Dermal papillae on head } \\
\text { Fin coloration }\end{array}$ & $\begin{array}{l}\text { Full, with } 36 \text { pores } \\
\text { Well defined }\end{array}$ & $\begin{array}{l}\text { Full, with } 35-37 \text { pores } \\
\text { Small } \\
\text { t dark blotches }\end{array}$ \\
\hline
\end{tabular}


Creative Commons licence, and indicate if changes were made. The images or other third party material in this article are included in the article's Creative Commons licence, unless indicated otherwise in a credit line to the material. If material is not included in the article's Creative Commons licence and your intended use is not permitted by statutory regulation or exceeds the permitted use, you will need to obtain permission directly from the copyright holder. To view a copy of this licence, visit http://creativecommons.org/licenses/by/4.0/.

\section{REFERENCES}

Berg, L.S., Ryby Turkestana (Fishes of Turkistan), St. Petersburg: Tipogr. I. Gol'dberga, 1905.

Berg, L.S., Ryby presnykh vod Rossiiskoi Imperii (Freshwater Fishes of the Russian Empire), Moscow: Dep. Zemledeliya, 1916.

Berg, L.S., Ryby presnykh vod SSSR $i$ sopredel'nykh stran (Freshwater Fishes of Soviet Union and Adjacent Countries), Leningrad: Vses. Gos. Nauchno-Issled. Inst. Ozern. Rechn. Rybn. Khoz., 1933, part 2, pp. 469-928.

Berg, L.S., Ryby presnykh vod SSSR $i$ sopredel'nykh stran (Freshwater Fishes of Soviet Union and Adjacent Countries), Moscow: Akad. Nauk SSSR, 1949, part 3, pp. 9291384.

Dukravets, G.M., Mamilov, N.Sh., and Mitrofanov, I.V., Fishes of Kazakhstan: annotated list, corrected and completed by December 31, 2016, Selevinia, 2016, vol. 24, pp. 47-71.

Kessler, K.F, Ichthyofauna of Turkistan: fishes, Izv. Imper. O-va Lyubitelei Estestvozn., Antropol., Etnogr., 1872, vol. 10, no. 1, pp. 47-79.

Koli, I., Geographical variation of Cottus gobio L. (Pisces, Cottidae) in Northern Europe, Ann. Zool. Fen., 1969, vol. 6, pp. 353-390.

Kottelat, M., European fresh water fishes: a heuristic checklist of the freshwater fishes of Europe (exclusive of former USSR), with an introduction for non-systematics comments nomenclature and conservation, Biologia (Bratislava), 1997, vol. 52, no. 5, pp. 1-271.

Kustareva, L.L. and Mamilov, N.Sh., Morphological variability of the bullheads (Cottus) - a new find in Kyrgyzstan, Nauka Nov. Tekhnol., 2012, no. 4, pp. 31-34.

Mitrofanov, I.V., Dukravets, G.M., Peseridi, N.E., et al., Ryby Kazakhstana. Tom 4. V'yunovye, Somovye, Aterinovye, Treskovye, Kolyushkovye, Uglovye, Okunevye, Bychkovye, Kerchakovye (Fishes of Kazakhstan, Vol. 4: Cobitidae, Siluridae, Atherinidae, Gadidae, Gasterosteidae, Syngnathidae, Percidae, Gobiidae, Cottidae), Alma-Ata: Nauka, 1989.

Neelov, A.V., Seismosensornaya sistema i klassfikatsiya kerchakovykh ryb (Cottidae: Myoxocephalinae, Artediellinae) (Seismosensory System and Classification of the Sculpins
(Cottidae: Myoxocephalinae, Artediellinae)), Leningrad: Nauka, 1979.

Nikol'skii, G.V., Ryby Tadzhikistana (Fishes of Tajikistan), Moscow: Akad. Nauk SSSR, 1938.

Sideleva, V.G., Neelov, A.V., Voronina, E.P., and Volkova, G.A., Katalog fondovykh kollektsii Zoologicheskogo Instituta RAN. Klass Kostistye ryby (Osteichthyes). Otryad skorpenoobraznye (Scorpaeniformes), podotryad Cottoidei. Chast' 1. Semeistva Scorpaenichthyidae, Ramphocottidae, Marukawichthyidae, Blepsiidae, Cottidae (podsemeistva Triglopsinae, Icelinae, Hemilepidotinae, Pseudoblenniinae, Oligocottinae, Gymnacanthinae, Ricuzeniinae, Myoxocephalinae, Radulinae, Nautichtyinae) (Catalogue of Research Collections of the Zoological Institute, Russian Academy of Sciences. Class Osteichthyes. Order Scorpaeniformes, Suborder Cottoidei, Part 1: Families Scorpaenichthyidae, Ramphocottidae, Marukawichthyidae, Blepsiidae, Cottidae (Subfamilies Triglopsinae, Icelinae, Hemilepidotinae, Pseudoblenniinae, Oligocottinae, Gymnacanthinae, Ricuzeniinae, Myoxocephalinae, Radulinae, Nautichtyinae)), St. Petersburg: Zool. Inst., Ross. Akad. Nauk, 2006.

Sideleva, V.G., Prirodina, V.P., Reshetnikov, Yu.S., and Zhidkov, Z.V., Redescription of Cottus koshewnikowi (Cottidae) and its morphological variability in tributaries of the upper Volga, J. Ichthyol., 2015a, vol. 55, no. 1, pp. 30-39. https://doi.org/10.1134/S0032945215010191

Sideleva, V.G., Naseka, A.M., and Zhidkov, Z.V., A new species of Cottus from the Onega River drainage, White Sea basin (Actinopterygii: Scorpaeniformes: Cottidae), Zootaxa, 2015b, vol. 3949, no. 3, pp. 419-430.

https://doi.org/10.11646/zootaxa.3949.3.7

Turdakov, A.F., the bullheads (genus Cottus) in Central Asia, Izv. Akad. Nauk Kirg. SSR, 1959, vol. 1, no. 4, pp. 125-136.

Turdakov, A.F., Ryby Kirgizii (Fish of Kyrgyzstan), Frunze: Akad. Nauk Kirg. SSR, 1963.

Vanina, T. and Stejskal, V., A new record of Cottus spinulosus in the Talas River watershed Kazakhstan Central Asia, $J$. Ichthyol., 2017, vol. 57, no. 4, pp. 547-552.

https://doi.org/10.1134/S003294521704018X

Yabe, M., Comparative osteology and mycology of the superfemaly Cottoidea (Pisces; Scorpaeniformes) and its phylogenetic classification, Mem. Fac. Fish. Hokkaido Univ., 1985, vol. 32, no. 1, pp. 1-130.

Yatsenko, A.L., Katalog kollektsii Zoologicheskogo kabineta Sankt-Peterburgskogo Universiteta. Tom 1. Ryby (Catalogue of Collections of the Zoological Department of the St. Petersburg University, Vol. 1: Fishes), St. Petersburg, 1896, pp. 63-99.

Zhidkov, Z.V., Sideleva, V.G., and Savinich, I.B., The scientific collection of fishes of Middle Asia in St. Petersburg State University: creation history and present state, Tr. Zool. Inst., Ross. Akad. Nauk, 2019, vol. 323, no. 4, pp. 395-411. https://doi.org/10.31610/trudyzin/2019.323.4.395

Translated by D.A. Pavlov 